\title{
Geostatistical assessment of trace metals in urban soils, Paraná, Brazil
}

Trace metals are common pollutants in urban soils thus making important the assessment of these pollutants. The main purpose of this study was investigated the concentrations of trace metals in urban soils in the industrial region of Curitiba, in the State of Paraná, Brazil and to examine the applicability of geostatistical modeling for assessing the environmental impact generated. For the analyses of trace elements, soil samples were collected at a depth of $0-20 \mathrm{~cm}$ and subjected to an acid digestion, in accordance with the $3050 \mathrm{~B}$ method. The identification of trace elements was through the technique Spectroscopy of Optical Emission. The soil texture was also analyzed and the data were determined by the compositional analysis method. For the geostatistical mapping it was used the software $R$, with the geoR package. The spatial variability of the sampled data was analyzed previously calculating the classic statistical indicators. The results indicated an approximated normal distribution of the data samples which is desirable. Then, the Matheron's classical estimator was used to compute the experimental semivariogram for several directions. No effect of anisotropy was shown. The semivariogram was fitted to three theoretical models: spherical, exponential and Gaussian. The results of cross validation of spherical model suggested that it is the best model among the others. Finally, the predictions of metals at unknown locations were obtained by ordinary kriging. In relation to the values obtained of metals and the standard values of the Brazilian referee legislation of management of contaminated sites, only one site had Ni levels higher than is allowed and other metals were ok. The generated map shows clearly the spatial variation of trace metals in the studied area. The results are suitable and suggest that the use of this methodology provides significant contributions to management of contaminated areas by different trace metals.

Keywords: Environmental Impact Assessment; Monitoring; Soils; Spatial Inference; Trace Elements.

\section{Avaliação geoestatística de metais traço em solos urbanos, Paraná, Brasil}

\begin{abstract}
Metais traços são poluentes comuns em solos urbanos, tornando importante a avaliação desses poluentes. $\mathrm{O}$ objetivo principal deste estudo foi investigar as concentrações de metais traço em solos urbanos da região industrial de Curitiba, no Estado do Paraná, Brasil e examinar a aplicabilidade da modelagem geoestatística para avaliação do impacto ambiental gerado. Para as análises de oligoelementos, amostras de solo foram coletadas na profundidade de $0-20 \mathrm{~cm}$ e submetidas à digestão ácida, de acordo com o método $3050 \mathrm{~B}$. A identificação dos oligoelementos foi por meio da técnica Espectroscopia de Emissão Óptica. A textura do solo também foi analisada e os dados determinados pelo método de análise composicional. Para o mapeamento geoestatístico, foi utilizado o software R, com o pacote geoR. A variabilidade espacial dos dados amostrados foi analisada previamente calculando os indicadores estatísticos clássicos. Os resultados indicaram uma distribuição normal aproximada das amostras de dados que é desejável. Em seguida, o estimador clássico de Matheron foi usado para calcular o semivariograma experimental para várias direções. Nenhum efeito da anisotropia foi mostrado. O semivariograma foi ajustado a três modelos teóricos: esférico, exponencial e gaussiano. Os resultados da validação cruzada do modelo esférico sugeriram que este é o melhor modelo entre os demais. Finalmente, as previsões de metais em locais desconhecidos foram obtidas por krigagem comum. Em relação aos valores obtidos dos metais e aos valores padrão da legislação da arbitragem brasileira de manejo de áreas contaminadas, apenas uma área apresentou teores de $\mathrm{Ni}$ acima do permitido e os demais metais estavam ok. O mapa gerado mostra claramente a variação espacial de metais traço na área estudada. Os resultados são adequados e sugerem que 0 uso desta metodologia fornece contribuições significativas para o gerenciamento de áreas contaminadas por diferentes metais traço.
\end{abstract}

Palavras-chave: Avaliação de Impacto Ambiental; Monitoramento; Solos; Inferência Espacial; Vestígios.

Topic: Engenharia Ambiental

Reviewed anonymously in the process of blind peer.
Received: 04/10/2020

Approved: $24 / 11 / 2020$
Willian Hoffmann Dib (iD)

Universidade Tecnológica Federal do Paraná, Brasil http://orcid.org/0000-0001-5283-542X william dib@hotmail.com

Janaína de Fátima Gonzalez Munster Cicarello (iD Universidade Tecnológica Federal do Paraná, Brasil http://lattes.cnpq.br/1372306361544865 http://orcid.org/0000-0003-1177-2244 janinha.cicarello@gmail.com

\section{Larissa Kummer (iD}

Universidade Tecnológica Federal do Paraná, Brasil http://lattes.cnpq.br/7892203021390255 http://orcid.org/0000-0002-8282-2045

Ikummer@utfpr.edu.br
Maurici Luzia Charnevski Del Monego (iD)

Universidade Tecnológica Federal do Paraná, Brasil

http://lattes.cnpq.br/1410424302920222

http://orcid.org/0000-0002-9093-3802

maurici@utfpr.edu.br
Referencing this:

DIB, W. H.; CICARELLO, J. F. G. M.; KUMMER, L.; MONEGO, M. L. C.. Geostatistical assessment of trace metals in urban soils, Paraná, Brazil. Revista Ibero Americana de Ciências Ambientais, v.11, n.6, p.358370, 2020. DOI: http://doi.org/10.6008/CBPC21796858.2020.006.0029

DOI: 10.6008/CBPC2179-6858.2020.006.0029 


\section{INTRODUCTION}

A good understanding of the soil system is the key to individual success and environmental harmony of any human activity related with the soil. The importance of pedological systems is increasingly recognized by business and political leaders, the scientific community, and all those who work with the land (BRADY et al., 2013).

Soil, as originally formed or as modified by humans, is the natural medium for the development of plants. This surface component belongs to the Earth's crust, which is under the constant action of external and internal agents that cause complex natural changes. There are phenomena that significantly affect the Earth's surface configuration, such as level fluctuations, earthquakes, folds and fractures, and the volcanic and metamorphic actions related to these, plus variation in depth, breakdown and transport caused by air, water or ice. Through these physical and chemical weathering, the products of disintegration of the bedrock are dragged and redistributed, and new portions of the lithosphere are accessible to atmospheric agents. Concomitantly, the accumulated sediments are subjected to further changes that may follow a new cycle of disintegration, transportation and deposition (COSTA, 2004).

Quantitatively, trace elements are negligible chemical constituents of the soil, but they are essential as micronutrients for plants. The first publications on trace elements were devoted to problems of plant nutrition. Later, it was recognized that the behavior of trace elements in the soil varies widely, and that these differences need to be better understood for the prediction and management of the status trace elements in soils. Even though some of these elements are mainly inherited from formed rock, their distribution in the profiles of the soil and their division between soil components reflect various pedogenic processes, as well as impacts caused by external factors, such as agricultural practices, pollution etc. (KABATA-PENDIAS, 2001).

The term trace element has been used to define cationic and anionic metals present in low concentrations (usually $<1 \mathrm{~g} \mathrm{~kg}^{-1}$ ) in soils and plants, although aluminum (Al), iron (Fe) and titanium (Ti), which occur in higher concentrations in the lithosphere, are also considered trace elements (FREIRE, 2011).

Trace elements, such as copper, cadmium, silver, arsenic, chromium and mercury, which are toxic at relatively low concentrations, persist in the environment and can accumulate to levels that disrupt plant growth and interfere with animal life. The debris from mining and industrial activities, as well as sewage sludge, are sources of potentially harmful concentrations of heavy metals (KUMMER et al., 2013).

For the detection and quantification of trace elements, the technique of emission spectroscopy using Optical Emission Spectrometry (ICP-OES) is fast, sensitive and convenient for detecting elements, including metals, in solution. All matrices, including ground water, aqueous samples, solid waste, soil, sludge, and sediments, among others, require procedures for sample digestion prior to analysis. The precision and accuracy of the results obtained using this method are sufficient for the execution of most analytic work (CSUROS et al., 2002).

The approaches that have been used for the analysis of environmental data, such as the concentration of trace elements in the soil, haven not been truly illuminating with regard to the actual 
impacts on the environment (MONEGO et al., 2010). Geostatistical methods are now being successfully used for the analysis and description of the spatial variability of soil properties. They represent an alternative approach for resolving the difficulties presented by traditional methods, such as high costs of monitoring campaigns, low data volume and sufficient time to perform all the necessary analyses (SABY et al., 2006).

The geostatistics methodology can be used in several areas and many researches have successfully integrated the method: in measuring the spatial dependence of rain and erosivity for the state of Ceará (RIBEIRO FILHO et al., 2017); for estimating the average annual temperature of the State of Bahia (ALMEIDA et al., 2020); in the spatial variability of barium in the area with oil well drilling residues (AMARAL SOBRINHO et al., 2018); in the evaluation of absolute positional accuracy of geospatial data (SANTOS, 2017). Other works applied geostatistical methods to predicting the distribution gradient of possible contamination by metals in various parts of the world (CHEN et al., 2008; GARCÍA-LORENZO et al., 2012; FINZGAR et al., 2014; NEZHAD et al., 2014). In one of his works, Lado et al. (2008) showed the application of geostatistics to model the distribution of eight trace elements ( $\mathrm{As}, \mathrm{Cd}, \mathrm{Cr}, \mathrm{Cu}, \mathrm{Hg}, \mathrm{Ni}, \mathrm{Pb}$ and $\mathrm{Zn}$ ).

According to the Institute for Urban Research and Planning of the municipality of Curitiba, state of Parana, the Regional $\mathrm{CIC}$ is located in the western portion of the municipality, bordering the municipalities of Campo Largo and Araucária. The total area of the region is 6,003 hectares, which corresponds to $13.81 \%$ of the territory of Curitiba. It consists of four districts: Industrial City of Curitiba (CIC), Augusta, São Miguel and Riviera. The $\mathrm{ClC}$ is the largest of the districts, corresponding to $68 \%$ of the territorial extension of the region. This district has a population density of 39.08 inhabitants/ha, with about 159,820 inhabitants in 2010 (IPPUC, 2014).

The conception of a predominantly industrial area and its implementation in Curitiba took place in 1973 when the area chosen had been declared as a public utility for purposes of expropriation. This action was accompanied by the formulation of an implementation proposal for what came to be known as the Industrial City of Curitiba (CIC). Changes in zoning in 1975 establish the $\mathrm{CIC}$ as a place intended primarily for industrial use, while impediments to new facilities in other areas of the city were created (MOURA et al., 2009).

According to socioeconomic data of the Curitiba Agency (2010), in 2004 this district had 818 industries and by 2010 it had increased to 1560 , reflecting a growth of $91 \%$. In addition, this district contains economic establishments in administration, with $31.49 \%$ for services, $46.18 \%$ for businesses and $21.62 \%$ for the industrial sector (CURITIBA, 2010).

The objective of this research was to investigate the soil heavy metal contents in the industrial area of Curitiba, Parana, modelling the spatial distribution by geostatistical methods.

\section{MATERIALS AND METHODS}

Initially, 34 georeferenced soil samples were collected in the CIC district of Curitiba, Paraná, from a depth of $20 \mathrm{~cm}$ (Figure 1). The soil samples were air-dried and sieved $(2 \mathrm{~mm})$ to obtain air-dried fine earth (ADFE). These samples were analyzed in the Soil Analyses Laboratory of the Federal University of Technology 
- Paraná (UTFPR). The soil texture was determined using the traditional soil analysis methods (EMBRAPA, 1997).

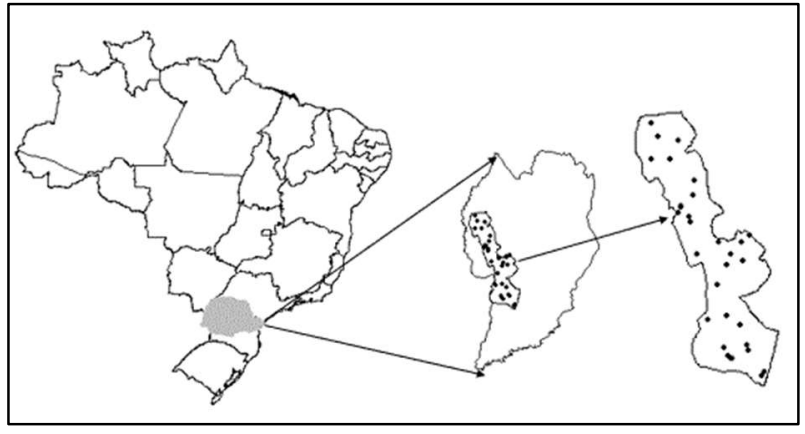

Figure 1: Map of the study site.

To analyze the compositional data of granulometry, it was used the package called "geoComp" developed by Martins (2010) and the package called "compositions" developed by Pawlowsky-Glahn et al. (2004), which considers the spatially distributed variables. The choice was made for being suitable for the analysis of data in proportions and that add up to $100 \%$.

For the analyses of trace elements, soil samples were subjected to an acid digestion process, in accordance with the 3050B method of Acid Digestion of Sediments, Sludges, and Soils, of the United States Environmental Protection Agency (USEPA, 1996). Using ICP-OES, analyses were performed for six potentially toxic trace metals: $\mathrm{Cd}$ (cadmium), $\mathrm{Cr}$ (chrome), $\mathrm{Cu}$ (copper), $\mathrm{Ni}$ (nickel), $\mathrm{Pb}$ (lead) and $\mathrm{Zn}$ (zinc).

Once the concentrations $\left(\mathrm{mg} \mathrm{kg}^{-1}\right)$ values of trace metals were the main steps for geostatistical analysis were followed, as suggested by the literature, using the R software and the package geoR (RIBEIRO JUNIOR et al., 2001), the R statistical computing project (R DEVELOPMENT CORE TEAM, 2016): determined, 1st) exploratory analyses of the data were performed; 2 nd) experimental semivariograms were constructed and modeled; 3rd) models of the semivariograms were subjected to adjustment methods, and validated using cross-validation; and 4th) the ordinary Kriging method was used for calculating predictions (ISAAKS et al., 1989; SOARES, 2000; CLARK et al., 2000; WACKERNAGEL, 2003).

The exploratory analysis, as a first step, consists of making a diagnosis of the characteristics of the available data. A descriptive and spatial statistical analysis were performed to assess the characteristics of the data, such as of the distribution, among others. Also, in this step, the existence of spatial dependence of the quantities under study was assessed. When spatial dependence was detected among the data, it was quantified by semivariogram. This function matches half of the variance, ie, the semivariance, of the differences among the values observed with the separation distance among these points. The interpretation of the semivariogram provides the degree of spatial continuity and dispersal mode of the variable which are used in the spatial prediction. Matheron's classical estimator of the semivariance was used in this study, whose computing Equation is (CRESSIE, 1993):

$$
\gamma(h)=\frac{1}{2 N(h)} \sum_{i=1}^{N(h)}\left[Z\left(x_{i}\right)-Z\left(x_{i}+h\right)\right]^{2}
$$

where $\gamma(h)$ is the semivariogram, $Z\left(x_{i}\right)$ is the concentration value measured at location $x_{i}, h$ 
is the lag distance and $N(h)$ is the number of pairs of measurements which are distance apart (CRESSIE, 1993; KITANIDIS, 1997). The experimental semivariogram is calculated for several lag distances.

After the construction of the experimental semivariogram, a theoretical model, from among spherical, exponential and Gaussian models, that best fit the conduct of the spatial data was chosen. To assist in choosing the best model, cross-validation was performed. This method chooses the model that best represents the behavior of the data based on the lowest statistical error.

The statistical error calculated were: mean error ME, the root mean squared error RMSE, the root mean kriging variance RMKV, the mean standardized error MSE, and the root mean squared standardized error RMSSE, computed respectively according to the following equations (WACKERNAGEL, 2003):

$$
\begin{aligned}
& M E=\frac{1}{N} \sum_{i=1}^{N}\left[\hat{Z}\left(x_{i}\right)-Z\left(x_{i}\right)\right] \\
& R M S E=\sqrt{\frac{1}{N} \sum_{i=1}^{N}\left[\hat{Z}\left(x_{i}\right)-Z\left(x_{i}\right)\right]^{2}} \\
& R M K V=\sqrt{\frac{1}{N} \sum_{i=1}^{N} \sigma^{2}\left(x_{i}\right)} \\
& M S E=\frac{1}{N} \sum_{i=1}^{N}\left[\frac{\left.\hat{Z}\left(x_{i}\right)-Z\left(x_{i}\right)\right]}{\sigma^{2}\left(x_{i}\right)}\right] \\
& R M S S E=\sqrt{\frac{1}{N} \sum_{i=1}^{N}\left[\frac{\hat{Z}\left(x_{i}\right)-Z\left(x_{i}\right)}{\sigma^{2}\left(x_{i}\right)}\right]^{2}}
\end{aligned}
$$

where $\hat{Z}\left(x_{i}\right)$ is the predicted value at cross-validation point $x_{i}, Z\left(x_{i}\right)$ is the actual (measured) value at point $x_{i}$,

$\mathrm{N}$ is the number of measurements of the data set, and $\sigma^{2}\left(x_{i}\right)$ is the kriging variance at cross-validation point. For a model that provides accurate predictions the ME should be close to zero, indicating that the predictions are unbiased. The RMSE should be as small as possible, indicating that the predictions are close to the measured values. The RMKV should be naturally as small as possible. If the kriging variances are accurate then the RMSSE should be close to 1 . If it is higher, the kriging prediction is too optimistic about the variability of the predictions (WACKERNAGEL, 2003).

Finally, the ordinary kriging method was used for interpolating unsampled points. This interpolation method provides not only a value, but also a measure of the uncertainty associated with the value, thus giving a better sense of the reliability of the estimated data. This method evalue the correlation of data over short distances by attributing greater weight to observations that are closer. Lastly, maps were developed showing the concentration gradient and dispersion in the study region of each of the trace elements analyzed. 


\section{RESULTS AND DISCUSSION}

The granulometric composition, that may express important soil properties, including soil classification, is the soil texture, being expressed through the relative proportion of sand, silt and clay - typical example of the compositional analysis (PEIXOTO et al., 2011; GRUNSKY, 2002). The histograms of sand, silt and clay fractions and the ternary diagram (Figure 2) present the compositions sampled.

The silt was the component that had the lowest value due to the distance of the points of the vertex of the diagram. In this diagram, points close to the vertex have high percentage of that component and low proportions of the other two components. There is a greater proportion of clay and sand in relation to the silt. The compositional analysis reveals that soil samples are predominantly sandy and clayey.

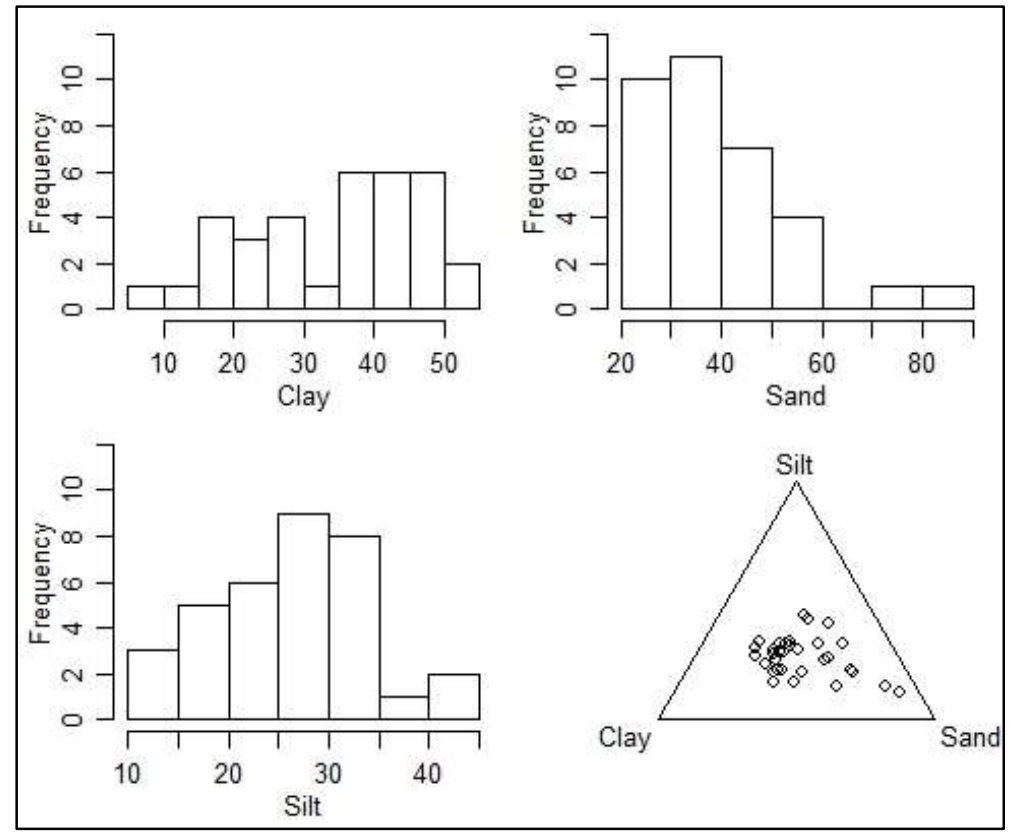

Figure 2: Distribution of Clay, Sand, Silt and the ternary diagram.

These characteristics are important to evaluate the potential of heavy metals to accumulate in the soil, since their presence in sandy soils is more significant, due to the possibility of them leaching out and reaching subterranean waters. The concentrations of six trace metals, $\mathrm{Cd}, \mathrm{Cr}, \mathrm{Cu}, \mathrm{Ni}, \mathrm{Pb}$ and $\mathrm{Zn}$, were subjected to geostatistical analysis. In Table 1 are presents the results of the descriptive statistical analysis of the concentrations (in $\mathrm{mg} \mathrm{kg}^{-1}$ ) of the element $\mathrm{Cd}$ in samples.

Table 1: Summary statistics of elements $\left(\mathrm{mg} \cdot \mathrm{kg}^{-1}\right)$.

\begin{tabular}{lllllll}
\hline Summary & $\mathbf{C d}$ & $\mathbf{P b}$ & $\mathbf{C u}$ & $\mathbf{C r}$ & $\mathbf{N i}$ & $\mathbf{Z n}$ \\
\hline Minimum & 0.04 & 7.70 & 8.92 & 12.35 & 3.77 & 12.32 \\
Lower quartile & 0.16 & 9.82 & 17.18 & 19.68 & 6.40 & 15.48 \\
Mean & 0.19 & 12.85 & 20.50 & 25.28 & 10.24 & 26.39 \\
Upper quartile & 0.20 & 14.59 & 22.64 & 28.61 & 8.96 & 34.16 \\
Median & 0.18 & 11.78 & 19.13 & 25.26 & 7.28 & 24.32 \\
Maximum & 0.57 & 31.11 & 48.69 & 49.36 & 78.76 & 58.64 \\
Variance & 0.007 & 21.78 & 47.99 & 72.06 & 156.08 & 160.12 \\
Standard deviation & 0.09 & 4.67 & 6.93 & 8.49 & 12.49 & 12.65 \\
Coefficient of variation & 46.29 & 36.05 & 33.39 & 33.58 & 122.00 & 47.95 \\
Coefficient of skewness & 2.45 & 1.82 & 1.86 & 0.74 & 4.84 & 0.86 \\
Kurtosis & 9.15 & 4.62 & 5.73 & 0.47 & 23.63 & -0.21 \\
\hline
\end{tabular}


These data serve as the basis for assessing the possibility of interpolation and generating a geostatistical map. The quartile graph, see Figure $3(\mathrm{I})$, shows that proximate points have similar values, and evidencing spatial dependence. Quantifying spatial dependence of is done using the semivariogram shown in Figure 3 (II). The distance adopted, in which correlations were especially observed among the data, was $1500 \mathrm{~m}$. The model chosen, with the help of cross-validation analysis, to generate the map of the estimates, was spherical. Can be observed in Figure 3 (III) the map of the estimates for the element Cd. A white color indicates a lower concentration (about $0.1 \mathrm{mg} \mathrm{kg}^{-1}$ ) and a dark color, near black, indicates higher concentrations (above $0.5 \mathrm{mg} \mathrm{kg}^{-1}$ ). Observing the map of the estimates, the highest concentrations of $\mathrm{Cd}$ can be seen in the central region, along with a more secluded spot in the south.

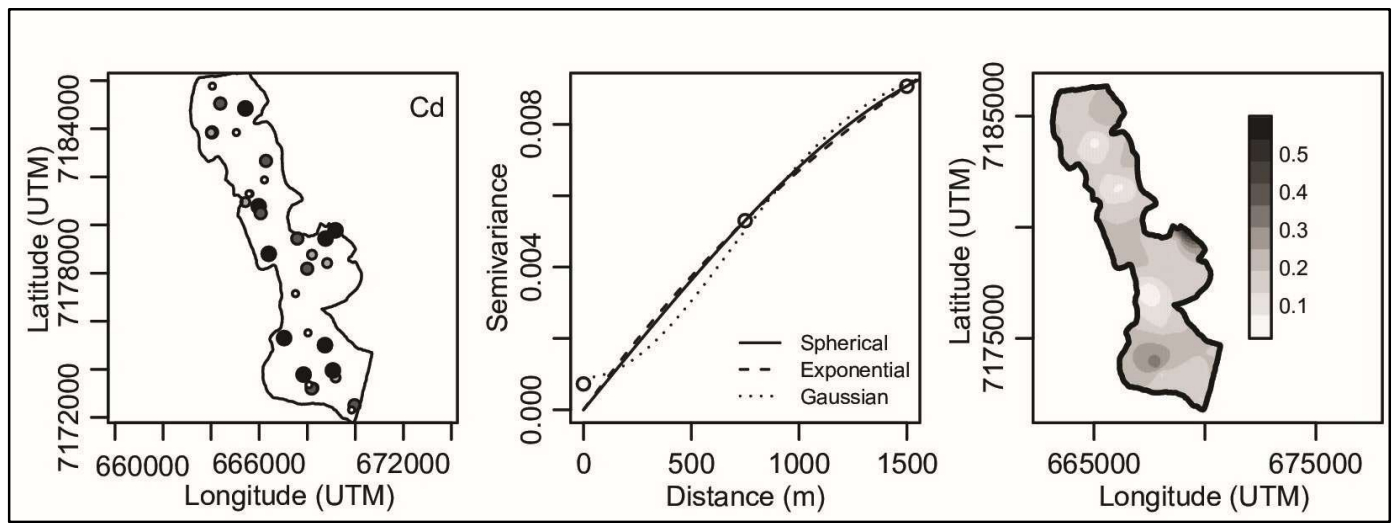

Figure 3: From left to right, Scatter plot quartiles of $\mathrm{Cd}(\mathrm{I})$, Omnidirectional experimental semivariogram and fitted models of Cd (II) and Prediction maps of Cd distribution using the spherical model (III).

Table 1 contains the results of the descriptive statistical analysis of the concentrations (in $\mathrm{mg} \mathrm{kg}^{-1}$ ) of the element $\mathrm{Pb}$ in samples. The skewness coefficient was 1.82, and the kurtosis coefficient was 4.62 , which indicates a broader curve.

Concentrations of $\mathrm{Pb}$ ranged from a minimum of $7.70 \mathrm{mg} \mathrm{kg}^{-1}$, to a maximum of $31.11 \mathrm{mg} \mathrm{kg}^{-1}$, which again shows homogeneity and near normality of the data. The distance adopted for the semivariogram was $340 \mathrm{~m}$. The quartile graph, Figure 4 (I), nearby points having similar values, confirming the existence of spatial dependence. The models tested for the experimental semivariogram (Figure 4 (II)). Both the spherical and the exponential models proved, according to the cross-validation analysis, suitable for generating the geostatistical map with appropriate parameters. The map was generated using the spherical model (Figure 4 (III)). In this map, the white colored area possesses lower concentrations (about $10 \mathrm{mg} \mathrm{kg}^{-1}$ ) of $\mathrm{Pb}$, and the dark color, almost black area, higher concentrations (above $30 \mathrm{mg} \mathrm{kg}^{-1}$ ). The map shows that the estimated values of $\mathrm{Pb}$ concentration in the central part of the region to be very high.

Can be observed in Table 1 the descriptive statistics for the concentrations (in $\mathrm{mg} \mathrm{kg}^{-1}$ ) of the element $\mathrm{Cu}$ in samples. A slight skewness was found, similar to the above metal (Pb), with a skewness coefficient of 1.86. The kurtosis coefficient was 5.73 , indicating a normal, but slightly tapered, curve. Concentrations of $\mathrm{Cu}$ varied from a minimum of $8.92 \mathrm{mg} \mathrm{kg}^{-1}$, to a maximum of $48.69 \mathrm{mg} \mathrm{kg}^{-1}$, again verifying that the range of values shows homogeneity of the data. 


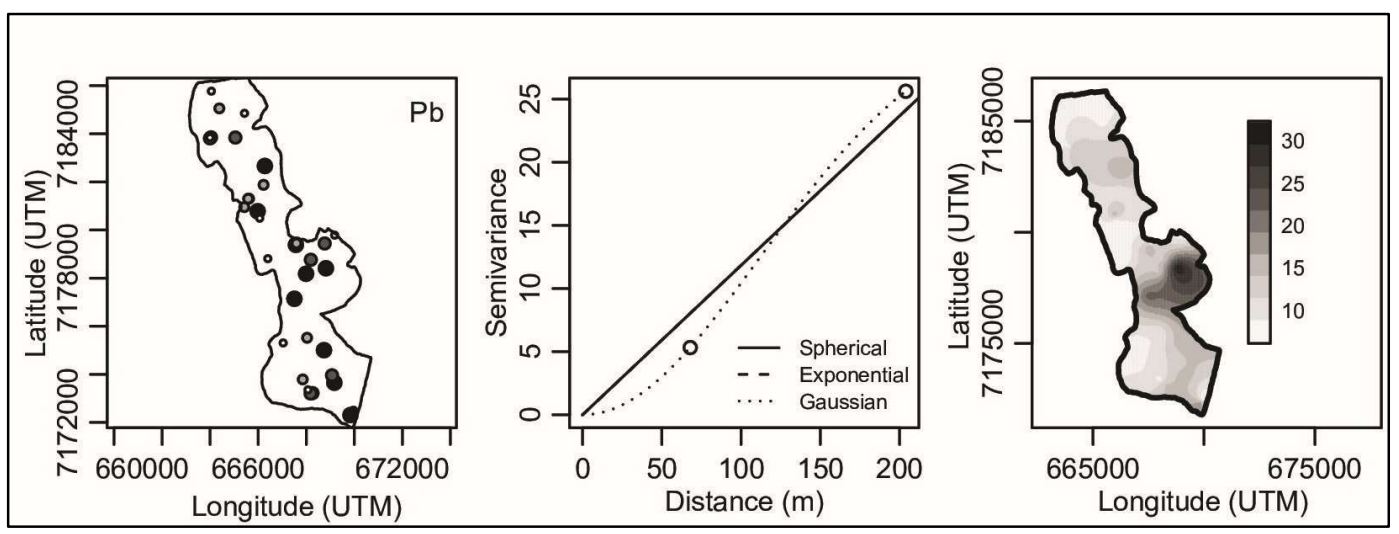

Figure 4: From left to right, Scatter plot quartiles of $\mathrm{Pb}(\mathrm{I})$, Omnidirectional experimental semivariogram and fitted models of $\mathrm{Pb}$ (II) and Prediction maps of $\mathrm{Pb}$ distribution using the spherical model (III).

Likewise, the quartile graph (Figure $5(I)$ ) provides evidence that there is spatial dependence, where it can be seen that lower value quartiles are closer, and higher value quartiles are further. The distance adopted, in which correlations were spatial observed among the data, was $90 \mathrm{~m}$. The model chosen, with the help of cross-validation analysis, to generate the map of the estimates, was exponential.

Can be observed in Figure 5 (III) the estimated variation in concentration of $\mathrm{Cu}$ for this area. The white color indicates lower concentrations (less than $20 \mathrm{mg} \mathrm{kg}^{-1}$ ) and the dark color, almost black, indicates higher concentrations (above $40 \mathrm{mg} \mathrm{kg}^{-1}$ ). The region with the dark color is a little above the center, a more tapered area of the map.

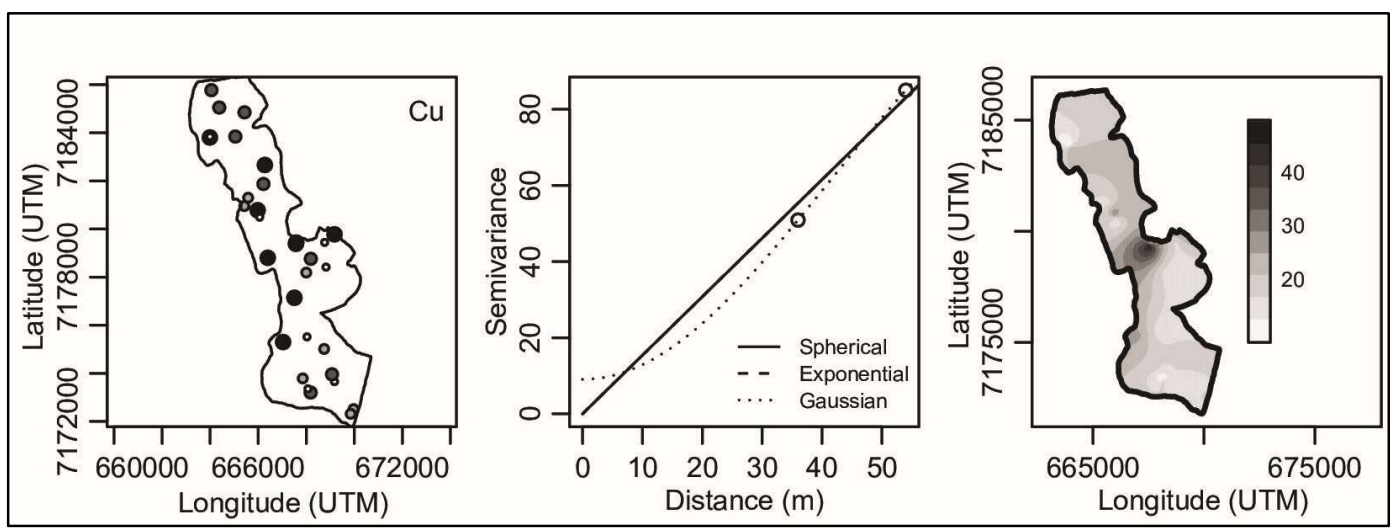

Figure 5: From left to right, Scatter plot quartiles of $\mathrm{Cu}(\mathrm{I})$, Omnidirectional experimental semivariogram and fitted models of $\mathrm{Cu}$ (II) and Prediction maps of Cu distribution using the exponential model (III).

The Table 1 are presenting the results of the descriptive statistics for the concentrations (in $\mathrm{mg} \mathrm{kg}^{-1}$ ) of the element $\mathrm{Cr}$ in samples. A slight skewness was found in the distribution of the data; with a skewness coefficient of 0.74 , and a kurtosis coefficient of 0.47 , the distribution is wider than a normal curve and is more similar to a Gaussian distribution. Concentrations of $\mathrm{Cr}$ varied from a minimum of $12.35 \mathrm{mg} \mathrm{kg}^{-1}$, to a maximum of $49.36 \mathrm{mg} \mathrm{kg}^{-1}$, demonstrating a relatively small amplitude.

In the quartile graph, Figure $6(\mathrm{I})$, some evidence of spatial dependence. To better understand the disposition of the data for $\mathrm{Cr}$, values of the variances were observed for all associated distances through a more detailed variogram analysis. It was found that in some cases very small distances had a large associated variance, and larger distances had smaller variances. The distance adopted for the semivariogram was 1000 $\mathrm{m}$. The models tested for the experimental semivariogram are shown in Figure 6 (II). The spherical model 
proved, according to the cross-validation analysis, suitable for generating the geostatistical map with appropriate parameters.

In the Figure 6 (III) the estimated variation in concentration of $\mathrm{Cr}$ for this area. The white color indicates lower concentrations (less than $20 \mathrm{mg} \mathrm{kg}^{-1}$ ) and the dark color, almost black, indicates higher concentrations (above $40 \mathrm{mg} \mathrm{kg}^{-1}$ ). Observing the map of the estimates, the highest concentrations of $\mathrm{Cr}$ can be seen in the central region, along with a more secluded spot in the south.

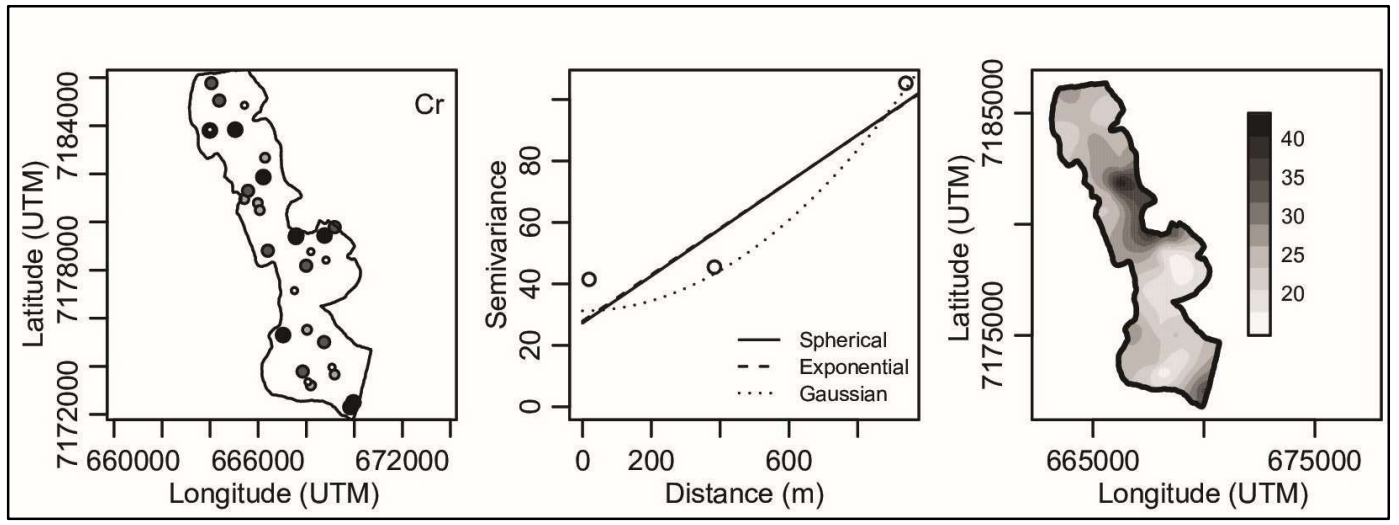

Figure 6: From left to right, Scatter plot quartiles of $\mathrm{Cr}(\mathrm{I})$, Omnidirectional experimental semivariogram and fitted models of $\mathrm{Cr}$ (II) and Prediction maps of $\mathrm{Cr}$ distribution using the spherical model (III).

In the Table 1 the results the descriptive statistics for the concentrations (in $\mathrm{mg} \mathrm{kg}^{-1}$ ) of the element $\mathrm{Ni}$ in samples. Note that there is skewness in the distribution of the data with a skewness coefficient of 4.84, and a kurtosis coefficient 23.63, which is a fairly normal, tapered curve. Concentrations of Ni varied from a minimum of $3.77 \mathrm{mg} \mathrm{kg}^{-1}$, to a maximum of $78.76 \mathrm{mg} \mathrm{kg}^{-1}$, showing that the amplitude is much higher than the previously analyzed elements $(\mathrm{Cd}, \mathrm{Cu}$ and $\mathrm{Pb})$. Still, the data is close to normal allowing interpolation to be performed.

The quartile graph in Figure 7 (I) gives us, again, evidence of spatial dependence. The distance adopted, at which correlation among the data was particularly observed, was $1500 \mathrm{~m}$. The experimental semivariogram was modeled (Figure 7 (II)) and the spherical model chosen to generate estimates because it had a greater range and better results from cross-validation than the other models. As was the case for $\mathrm{Cd}$, the higher concentrations are located in the central corner on the far right of the map, as can be seen in Figure 7 (III). The remaining area of the region has estimated values lower than $20 \mathrm{mg} \mathrm{kg}^{-1}$.

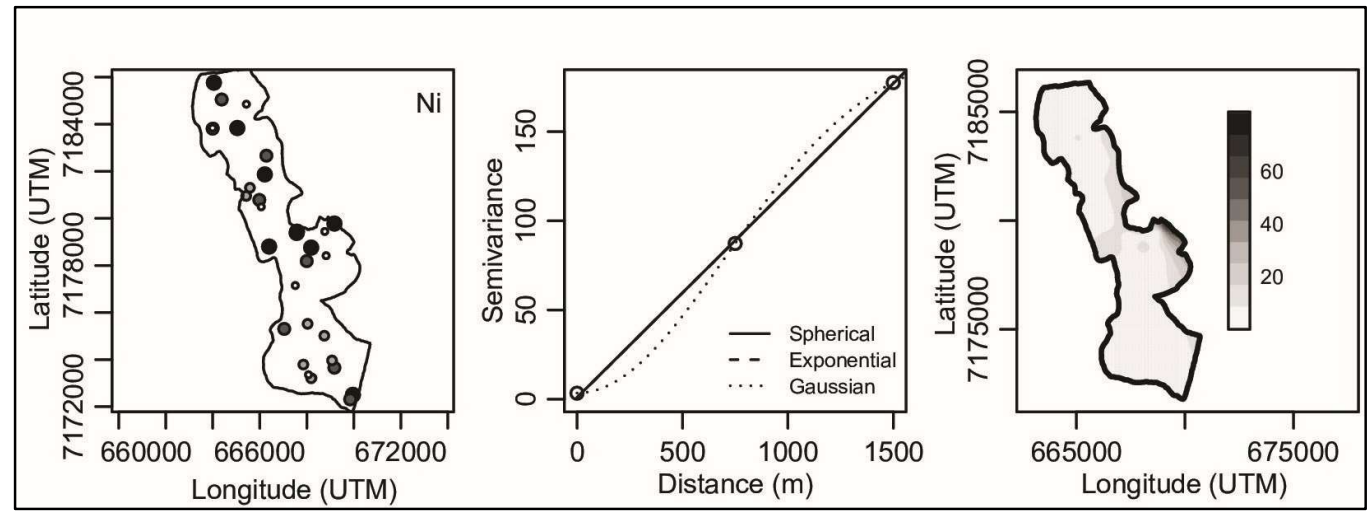

Figure 7: From left to right, Scatter plot quartiles of $\mathrm{Ni}(\mathrm{I})$, Omnidirectional experimental semivariogram and fitted models of $\mathrm{Ni}$ (II) and Prediction maps of Ni distribution using the spherical model (III). 
It is important to highlight that there was only one point with Ni content above the values established by Brasil (2009) as "Prevention" (value = $30 \mathrm{mg} \mathrm{kg}^{-1}$ ) and "Investigation for agricultural area" (value = $70 \mathrm{mg}$ kg-1). At this point, greater care is suggested because, besides the values being high, the soil of this place is sandy, reaching $82 \%$ of sand in its composition and only $7 \%$ of clay. In this case, the risk of leaching is very large. This place is located between a paved street and a ditch, in front of an industrial condominium. The characteristics of the sampling site do not explain the value found, revealing that some unexpected event may have occurred for this high value.

Table 1 contains the results of the analysis of the descriptive statistics for the concentrations (mg kg$\left.{ }^{1}\right)$ of the element $\mathrm{Zn}$ in the samples. The skewness coefficient was 0.86 , the lowest value from among the previously analyzed metals. The kurtosis coefficient was less than zero $(-0.21)$, indicating a wider curve than the conventional Gaussian distribution.

The quartile graph in Figure 8 (I) confirms the existence of close points with similar values, giving evidence of spatial dependence. The minimum concentration was $12.32 \mathrm{mg} \mathrm{kg}^{-1}$, and the maximum 58.64 mg $\mathrm{kg}^{-1}$. The cutting distance adopted for the semivariogram, at which there was particular correlation among the data, was $600 \mathrm{~m}$. Again, the spherical model (Figure 8 (II)) was used to generate the map of the estimates.

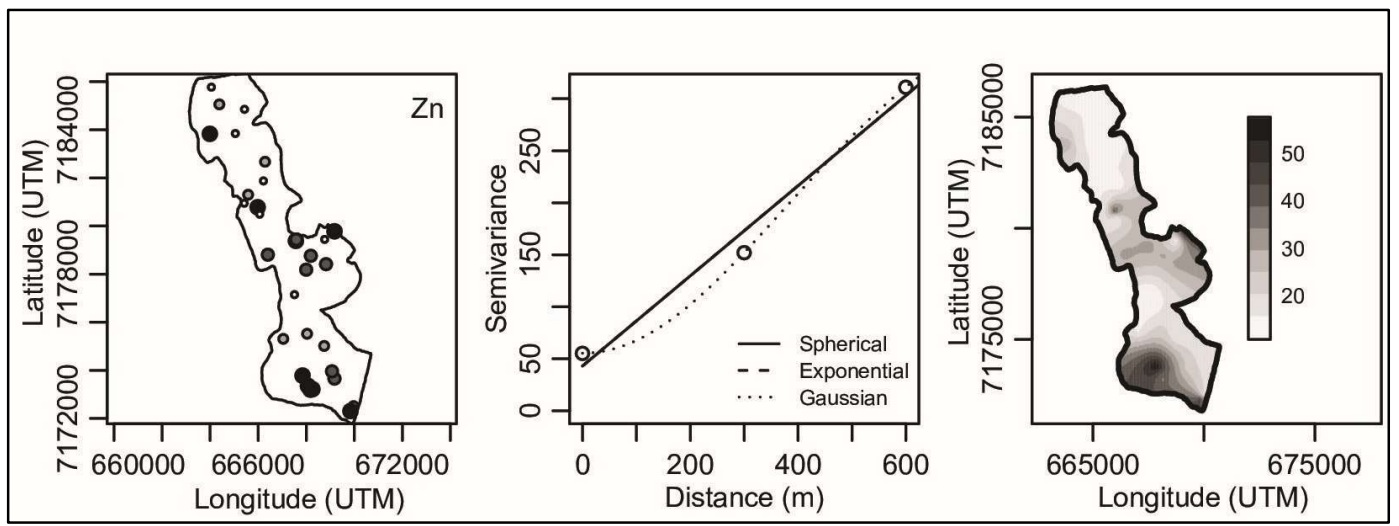

Figure 8: From left to right, Scatter plot quartiles of $\mathrm{Zn}(\mathrm{I})$, Omnidirectional experimental semivariogram and fitted models of $\mathrm{Zn}$ (II) and Prediction maps of Zn distribution using the spherical model (III).

Figure 8 (III) refers to the variation in the estimated concentration of $\mathrm{Zn}$ for this region. The white color indicates lower concentrations (below $20 \mathrm{mg} \mathrm{kg-1)} \mathrm{and} \mathrm{the} \mathrm{dark} \mathrm{coloration,} \mathrm{close} \mathrm{to} \mathrm{black,} \mathrm{indicates}$ higher concentrations (around $50 \mathrm{mg} \mathrm{kg-1).} \mathrm{Concomitant} \mathrm{with} \mathrm{the} \mathrm{maps} \mathrm{of} \mathrm{Ni}$ and $\mathrm{Cd}$, the highest estimate concentrations of $\mathrm{Zn}$ are in the central region to the right. In addition, a large region lower on the map also has high levels of this metal.

The visual assessment of the uncertainty map shows clearly the spatial variation of trace metals in studied area. The concentrations of trace elements were below of the prevention and intervention residential values of the Brazilian Resolution that is used as a referee legislation of management of contaminated sites (BRASIL, 2009). Although according to the legislation the values are ok, comparing all maps obtained, there is a trend of higher estimated concentrations being found in the central region of the map, and lower concentrations in the upper region.

In order to verify the percentage contribution of each metal in relation to the total content, the data 
were normalized (TOLOSANA-DELGADO et al., 2011). There is predominance of $\mathrm{Cr}$ and $\mathrm{Zn}$ in the samples, reaching values up to $48 \%$ for $\mathrm{Zn}$ (Table 2 ).

Table 2: Concentration of metals in the samples of soils.

\begin{tabular}{|c|c|c|c|c|c|c|}
\hline Samples & $\mathrm{Cd}(\%)$ & $\mathrm{Pb}(\%)$ & $\mathrm{Cu}(\%)$ & $\mathrm{Cr}(\%)$ & $\mathrm{Ni}(\%)$ & Zn (\%) \\
\hline Sample 1 & 0.26 & 17.45 & 22.54 & 28.49 & 9.17 & 22.09 \\
\hline Sample 2 & 0.16 & 12.10 & 22.24 & 30.75 & 8.42 & 26.34 \\
\hline Sample 3 & 0.26 & 13.11 & 12.62 & 20.08 & 5.47 & 48.46 \\
\hline Sample 4 & 0.17 & 13.09 & 23.24 & 20.11 & 6.26 & 37.14 \\
\hline Sample 5 & 0.22 & 13.23 & 21.35 & 39.46 & 8.84 & 16.89 \\
\hline Sample 6 & 0.16 & 17.89 & 23.46 & 27.56 & 7.91 & 23.03 \\
\hline Sample 7 & 0.16 & 16.52 & 18.32 & 31.00 & 7.39 & 26.61 \\
\hline Sample 8 & 0.15 & 11.90 & 33.42 & 24.41 & 6.35 & 23.76 \\
\hline Sample 9 & 0.15 & 9.17 & 22.71 & 36.21 & 11.23 & 20.52 \\
\hline Sample 10 & 0.28 & 15.67 & 19.75 & 29.36 & 9.15 & 25.80 \\
\hline Sample 11 & 0.21 & 18.53 & 18.66 & 25.52 & 8.94 & 28.14 \\
\hline Sample 12 & 0.19 & 15.16 & 15.97 & 17.76 & 6.84 & 44.08 \\
\hline Sample 13 & 0.21 & 14.70 & 19.79 & 22.83 & 7.16 & 35.32 \\
\hline Sample 14 & 0.17 & 11.85 & 12.78 & 22.06 & 6.18 & 46.96 \\
\hline Sample 15 & 0.21 & 8.74 & 19.72 & 42.78 & 10.57 & 17.97 \\
\hline Sample 16 & 0.12 & 14.59 & 14.00 & 26.33 & 7.13 & 37.83 \\
\hline Sample 17 & 0.20 & 13.54 & 19.25 & 27.61 & 9.41 & 29.99 \\
\hline Sample 18 & 0.27 & 18.12 & 21.05 & 31.49 & 7.79 & 21.28 \\
\hline Sample 19 & 0.20 & 11.45 & 24.66 & 35.48 & 10.87 & 17.33 \\
\hline Sample 20 & 0.23 & 12.71 & 23.44 & 32.88 & 8.92 & 21.82 \\
\hline Sample 21 & 0.08 & 14.25 & 23.69 & 33.36 & 13.81 & 14.80 \\
\hline Sample 22 & 0.16 & 12.70 & 30.55 & 23.35 & 15.04 & 18.20 \\
\hline Sample 23 & 0.22 & 14.84 & 21.64 & 26.72 & 9.14 & 27.45 \\
\hline Sample 24 & 0.28 & 8.83 & 15.03 & 23.47 & 5.89 & 46.50 \\
\hline Sample 25 & 0.24 & 10.95 & 29.03 & 32.79 & 9.18 & 17.81 \\
\hline Sample 26 & 0.06 & 27.43 & 27.06 & 24.38 & 6.25 & 14.83 \\
\hline Sample 27 & 0.15 & 13.32 & 19.66 & 24.09 & 14.46 & 28.32 \\
\hline Sample 28 & 0.28 & 4.35 & 12.94 & 17.59 & 38.38 & 26.46 \\
\hline Sample 29 & 0.26 & 15.10 & 20.38 & 43.74 & 5.97 & 14.55 \\
\hline Sample 30 & 0.17 & 31.26 & 15.13 & 14.99 & 6.46 & 31.99 \\
\hline Sample 31 & 0.22 & 7.01 & 24.92 & 25.56 & 14.73 & 27.57 \\
\hline Sample 32 & 0.27 & 12.29 & 21.71 & 36.76 & 8.03 & 20.94 \\
\hline Sample 33 & 0.08 & 9.91 & 20.19 & 45.59 & 10.83 & 13.40 \\
\hline Sample 34 & 0.34 & 14.15 & 27.76 & 30.06 & 8.22 & 19.47 \\
\hline
\end{tabular}

Although these two metals are in higher proportions in relation to the others, they do not represent risk, because in comparison to the values of the Brazilian Resolution that is used as a referee legislation of management of contaminated sites, the values obtained are below of the "Prevention" values, which are 75 mg kg-1 for $\mathrm{Cr}$ and $300 \mathrm{mg} \mathrm{kg}-1$ for Zn (BRASIL, 2009).

The higher concentration of trace metal could be associated with vehicular emission and industries that might have contributed to increase the level of these metals in the urban soils analyzed. Therefore, even the concentration of detected metals was low, is it important to do assessments of soil quality in urban regions to allow sustainable management of urban resources. The elevated levels of these metals could cause serious threatens for the population and environment health (KUMMER et al., 2011).

\section{CONCLUSIONS}

Our study demonstrates that geostatistical analysis can provide good estimates of trace metals very valuable for environmental impact assessment. It is an excellent decision-making vehicle regarding the quality of the soil both in verification and environmental monitoring, without major investment in sampling. 
Such geostatistical maps have allowed a better view of the dispersion of the analyzed trace metals.

Regarding the legal aspect of concentrations of heavy metals in the sampling sites, the values found were almost all below the values established by the Brazilian legislation as 'Prevention', being an indicative of the maintenance of soil quality in relation to these toxic elements, even being in a typically industrial region.

The presence of $\mathrm{Ni}$ in concentrations higher than the legislation in only one point of the region shows a situation that is punctual and must be investigated, mainly because it is associated with high levels of sand, generating concern about possible contamination of groundwater.

AKNOWLEDGEMENT: The authors wish to thank Federal University of Technology - Paraná (UTFPR) and National Council for Scientific and Technological Development (CNPq) for funding support.

\section{REFERENCES}

ALMEIDA, S. L. H.; CAPELINI, V. A.; ROSAS, J. T. F.; OLIVEIRA, G. D.; LIMA, J. S. S.; SILVA, S. A.. Geoestatística multivariada para a estimativa da temperatura média anual no Estado da Bahia, Brasil. Revista Univap, São José dos Campos, v.22 n.40, 2017. DOI: http://dx.doi.org/10.18066/revistaunivap.v22i40.1636

AMARAL SOBRINHO, N. M. B. A.; CEDDIA, M. B.; ZONTA, E.; MAGALHÃES, M. O. L.; FREITAS, F. C.; LIMA, E. S. A.. Spatial variability and solubility of barium in a petroleum welldrilling waste disposal area. Environmental Monitoring and Assessment, v.190, n.228, p.1-11, 2018. DOI: https://doi.org/10.1007/s10661-018-6566-x

BRADY, N. C.; WEIL, R. R.. Elementos da natureza e propriedades dos solos. 3 ed. Porto Alegre, Bookman, 2013.

BRASIL. Resolução CONAMA n. 420, de 28 de janeiro de 2009. Dispõe sobre critérios e valores orientadores de qualidade do solo quanto à presença de substâncias químicas e estabelece diretrizes para o gerenciamento ambiental de áreas contaminadas por essas substâncias em decorrência de atividades antrópicas. Brasília: DOU, 2009.

CHEN, T.; LIU, X.; ZHU, M.; WU, K. Z. J.; XU, J.; HUANG, P.. Identification of trace element sources and associated risk assessment in vegetable soils of the urban-rural transitional area of Hangzhou, China. Environmental Pollution, v.151, p.67-78, 2008. DOI:

https://doi.org/10.1016/j.envpol.2007.03.004

CLARK, I.; HARPER, W. V.. Practical Geostatiscs. Columbus: Ecosse North America LLC, 2000.

COSTA, J.. Caracterização e Constituição do solo. Lisboa, Fundação Calouste Gulbenkian, 2004.

CRESSIE, N. A. C.. Statistics for Spatial Data. Des Moines: John Wiley \& Sons, 1993.

CSUROS, M.; CSUROS C.. Environmental sampling and analysis for metals. Boca Raton: CRC Press, 2002.

CURITIBA. Atividades econômicas, Curitiba, regional CIC
(SMF) - 2004 a 2010. Curitiba: DOE: 2010.

EMBRAPA. Manual de métodos de análise de solo. Centro Nacional de Pesquisa de Solos. 2 ed. Rio de Janeiro: EMBRAPA, 1997.

FINZGAR, N.; JEZ, E.; VOGLAR, D.; LESTAN, D.. Spatial distribution of metal contamination before and after remediation in the Meza Valley, Slovenia. Geoderma, 217 218:135-143, 2014. DOI:

https://doi.org/10.1016/i.geoderma.2013.11.011

FREIRE, G.. Caracterização química, física e teores de elementos-traço em solos de diferentes ambientes no Rio Grande do Norte. Dissertação (Mestrado) - Universidade Federal Rural do Semiárido, Natal, 2011.

GARCÍA-LORENZO, M. L.; PÉREZ-SIRVENT, C.; MARTÍNEZSANCHEZ, M. J.; MOLINA-RUIZ, J.. Trace elements contamination in an abandoned mining site in a semiarid zone. Journal of Geochemical Exploration, v.113, p.23-35, 2012. DOI: https://doi.org/10.1016/j.gexplo.2011.07.001

GRUNSKY, E. C.. Statistical analysis in the geosciences, In: ATKINSON, P. M.. Encyclopaedia of Life Support Systems (EOLSS). Oxford: EOLSS Publishers, 2002.

ISAAKS, E. H.; SRIVASTAVA, R. M.. Applied Geostatistics New York, Oxford University Press, 1989.

IPPUC. Instituto de Pesquisa Planejamento Urbano de Curitiba. A Cidade que Queremos: Regional CIC. IPPUC, 2014.

KABATA-PENDIAS, A.. Trace elements in soils and plants. 4 ed. Boca Raton: CRC Press, 2001.

KITANIDIS, P. K.. Introduction to Geostatistics: Applications in Hydrogeology. Cambridge: Cambridge University Press, 1997.

KUMMER, L.; MELO, V. F.; BARROS, Y. J.; AZEVEDO, J. C. R.. Extrações sequenciais de chumbo e zinco em solos de área de mineração e metalurgia de metais pesados. Revista 
Brasileira de Ciência do Solo, v.35, p.2005-2018, 2011. DOI: http://dx.doi.org/10.1590/S0100-06832011000600017

KUMMER, L.; MELO, V. F.; BARROS, Y. J.. Lead and zinc in the structure of organic and mineral components of soils.

Revista Brasileira de Ciência do Solo, v.37, p.438-449, 2013. DOI: https://doi.org/10.1590/S0100-06832013000200015

LADO, L. R.; HENGL, T.; REUTER, H. I.. Heavy metals in European soils: A geostatistical analysis of the FOREGS Geochemical database. Geoderma, v.148, p.189-199, 2008. DOI: https://doi.org/10.1016/j.geoderma.2008.09.020

MARTINS, A. B. T.. Análise geoestatística para dados composicionais. Tese de Doutorado. Universidade Federal do Paraná, Curitiba, 2010.

MONEGO, M. L. C. D.; RAMOS, P.; NEVES, M. V.. Avaliação de impacto ambiental de descargas de águas residuais usando uma metodologia geoestatística. Revista Brasileira de Recursos Hídricos, v.15, n.3, p.57-68, 2010. DOI: http://dx.doi.org/10.21168/rbrh.v15n3.p57-68

MOURA, R.; FIRKOWSKI, O. L. C. F.. Dinâmicas intrametropolitanas e produção do espaço na Região Metropolitana de Curitiba. Rio de Janeiro: Letra Capital, 2009.

NEZHAD, M. T. K.; MOHAMMADI, K.; GHOLAMI, A.; HANI, A.; SHARIAT, M. S.. Cadmium and mercury in topsoils of Babagorogor watershed, western Iran: Distribution, relationship with soil characteristics and multivariate analysis of contamination sources. Geoderma, v.219-220, p.177-185, 2014. DOI: https://doi.org/10.1016/j.geoderma.2013.12.021

PEIXOTO, A. P. B.; SANTANA, T. V. F.; HISSA, H. R.; SILVA, E. F.; MACEDO, J. R.; CAPECHE, C. L.; OLIVEIRA, M. C. N.. Análise Espacial de Dados Composicionais. In: RBRAS, 56; SEAGRO, 14. Anais. Maringá, 2011.

PAWLOWSKY-GLAHN, V.; OLEA, R. A.. Geostatistical analysis of compositional data. New York: Oxford University Press,
2004.

R DEVELOPMENT CORE TEAM. R: A Language and environment for statistical computing. Vienna: R Foundation for Statistical Computing, 2016

RIBEIRO FILHO, J. C.; SANTOS, J. C. N.; ARUAJO NETO, J. R.; LEMOS FILHO, L. C. A.; BRASIL, J. B.. Estimativa das erosividades anuais e mapeamento para o Estado do Ceará. Revista Geonorte, v.8, n.30, p.1-15, 2017. DOI: https://doi.org/10.21170/geonorte.2017.V.8.N.30.1.15

RIBEIRO JUNIOR, P. J.; DIGGLE, P. J.. geoR: a package for geostatistical analysis. R-NEWS, v.1, p.15-18, 2001.

SABY, N.; ARROUAYS, D.; BOULONNE, L.; JOLIVET, C.; POCHOT, A.. Geostatistical assessment of $\mathrm{Pb}$ in soil around Paris, France. Science of the Total Environment, v.367, p.212-221, 2006. DOI:

https://doi.org/10.1016/j.scitotenv.2005.11.028

SANTOS, A. S.; MEDEIROS, N. G.; SANTOS, G. R.. LISBOA FILHO, J.. Uso da Geoestatística na Avaliação da Acurácia Posicional Absoluta de dados Geoespaciais. Boletim de Ciências Geodésicas, v.23, n.3, p.405-418, 2017. DOI: https://doi.org/10.1590/s1982-21702017000300027

SOARES, A.. Geoestatística para as Ciências da Terra e do Ambiente. Coleção Ensino da Ciência e da Tecnologia. Lisboa: IST Press, 2000.

TOLOSANA-DELGADO, R.; OTERO, N.; PAWLOWSKY-GLAHN, V.. Some Basic Concepts of Compositional Geometry. Mathematical Geology, v.37, n.7, p.673-680, 2005. DOI: https://doi.org/10.1007/s11004-005-7374-8

USEPA. United States Environmental Protection Agency. Method 3050B - Acid digestion of sediments, sludges, and soils. USEPA, 1996.

WACKERNAGEL, H.. Multivariate Geostatistics: an introduction with applications. Berlin: Springer Heidelberg, 2003.

A CBPC - Companhia Brasileira de Produção Científica (CNPJ: 11.221.422/0001-03) detém os direitos materiais desta publicação. Os direitos referem-se à publicação do trabalho em qualquer parte do mundo, incluindo os direitos às renovações, expansões e disseminações da contribuição, bem como outros direitos subsidiários. Todos os trabalhos publicados eletronicamente poderão posteriormente ser publicados em coletâneas impressas sob coordenação da Sustenere Publishing, da Companhia Brasileira de Produção Científica e seus parceiros autorizados. Os (as) autores (as) preservam os direitos autorais, mas não têm permissão para a publicação da contribuição em outro meio, impresso ou digital, em português ou em tradução. 